\title{
How to win the battle for survival as a school subject? Reflections on justification, objectives, methods and organization of PE in schools of the $21^{\text {st }}$ century ${ }^{1}$ \\ ¿Cómo ganar la batalla por la supervivencia como materia escolar? Reflexiones sobre la justificación, los objetivos, los métodos y la organización de la Educación Física en las escuelas del siglo XXI \\ BartCrum \\ Free University, Amsterdam (Nederland)
}

Summary. This paper starts with the observation that in many countries around the world school PE is sailing in rough waters and in real danger of losing its position in the curriculum. A second observation is that this situation is due to confusion in and failure of the PE profession itself. Too many physical educators speak about 'teaching PE' without any evidence of an intention to produce learning. Consequently, PE in the reality of our public schools does not achieve the profile of a relevant teaching-learning activity and therefore is losing political and public support. Next, it is argued that the precarious position of the PE profession can, at least partly, be explained by the ideological legacy of the profession. Two longstanding PE ideologies - namely «the training-of-the physical» concept and «the education-through-the-physical» concept - which were constructed in order to gain respect and recognition, continue to negatively influence the perspectives of physical educators and their practices in schools. Both concepts induce non-teaching PE practices. The first ideology leads to PE as fitness training, the latter to PE as supervised recess or entertainment. In conclusion: in order to save PE as part of the curriculum, the profession needs a new paradigm, a new way of theoretical thinking and a new way of acting in practice. The paper goes on to outline the main characteristics of a new paradigm and the following issues are discussed: (a) justification as a school subject, (b) objectives of 'teaching movement and sport', (c) view of human movement, (d) didactical principles and (e) an 'ecological' curriculum and institutional openness. For the justification of 'teaching movement and sport' (a better label than PE), the following starting assumptions are applied: the school should concentrate on subjects that (1) are emancipating because they prepare youngsters for a relevant, humane and independent participation in social-cultural life; (2) can be arranged according to the typical institutional status of the school; and (3) cannot be fulfilled better by other socialization agencies. The justification can be summarized in three propositions:

- In modern societies participation in movement culture contributes to the quality of life of many of its members.

-A lasting and satisfying participation in movement culture demands a repertoire of competencies that does not come automatically to people and thus requires organized teaching-learning processes.

- Since every youngster goes to school for at least 12 years and since schools are provided with professional teachers, the responsibility for the introduction into movement culture should be in the hands of the school.

'Planned introduction into movement culture' is seen as an appropriate label for the teaching-learning process in schools and 'competencies for lasting participation in movement culture' as a general label for the desired outcomes. Objectives of 'teaching movement and sport' are then specified and formulated in terms of affective learning (learning to like to be active, to play, to participate in sport), technomotor learning, sociomotor learning and cognitive / reflective learning. Next the view of human movement is discussed. Because of its educational productivity a 'relational' view of the body and a 'relational' view of human movement are recommended instead of the traditional substantial view of the body and the Newtonian view of movement. Teaching movement and sport is not about the physical, the body machine, but about children moving and teaching them how to move, teaching how to solve movement problems. In line with this view two didactical principles are elaborated on namely (1) problem orientation, and (2) student orientation. The final paragraph contains a plea in favor of 'ecological' curricula and institutional openness.

Keywords: identity crisis of PE, failing traditional ideologies, paradigm shift, justification as school subject, objectives, view of movement, problem orientation, student orientation, ecological curricula.

Resumen. En este trabajo se inicia con la observación que en muchos países de todo el mundo la Educación Física Escolar (EF) está navegando en aguas turbulentas y en peligro real de perder su posición en el currículo. La segunda observación es que esta situación se debe a la confusión y fracaso de la propia profesión de EF. Demasiados educadores físicos hablan de «enseñar EF» sin ninguna evidencia de la intención de producir aprendizaje. En consecuencia, la educación física en la realidad de nuestras escuelas públicas no logra el perfil de la actividad de enseñanza-aprendizaje relevante y por lo tanto está perdiendo apoyo político y público. A continuación, se argumenta que la situación precaria de la profesión EF puede, al menos en parte, ser explicada por el legado ideológico de la profesión. Dos ideologías de EF desde que hace mucho tiempo - a saber, el concepto de «la capacitación física» y el concepto de «la educación a través del físico» - fueron construidos con el fin de ganar el respeto y el reconocimiento, siguen influyendo negativamente las perspectivas de los educadores físicos y sus prácticas en las escuelas. Ambos conceptos inducen prácticas denon enseñanza en educación física. La primera ideología conduce al entrenamiento de fitness, la segunda a una EF como un recreo o entretenimiento supervisado. En conclusión: con el objetivo de mantener la EF en el currículo, la profesión necesita un nuevo paradigma, una nueva forma de pensamiento teórico y una nueva forma de actuar en la práctica. En el artículo se pasa a describir las principales características del nuevo paradigma y se discuten las cuestiones siguientes: (a) la justificación como materia escolar, (b) los objetivos de 'la enseñanza del movimiento y el deporte’, (c) una visión del movimiento humano (d) los principios didácticos y (e) un currículo ‘ecológico’ y la apertura institucional. Para la justificación de la «enseñanza del movimiento y el deporte» (un nombre más adecuado que EF), se aplican los supuestos de partida siguiente: La escuela debe concentrarse en temas que (1) son emancipadores porque preparan los jóvenes para la participación relevante, humana e independiente en la vida social y cultural; (2) pueden organizarse de acuerdo con el estatus institucional típico de la escuela; y (3) no pueden ser mejor cumplidos por otras agencias de socialización. La justificación se puede resumir en tres proposiciones:

- En las sociedades modernas, la participación en la cultura del movimiento contribuye para la calidad de vida de muchos de sus miembros.

- Una participación duradera y satisfactoria en la cultura del movimiento exige un repertorio de competencias que no viene automáticamente a las personas y que requiere en consecuencia procesos de enseñanza-aprendizaje organizados.

- Debido a que cada joven va a la escuela por lo menos 12 años y que las escuelas cuentan con maestros profesionales, la responsabilidad de la introducción en la cultura del movimiento debería estar en las manos de la escuela.

«Introducción intencional en la cultura del movimiento» es una designación adecuada para el proceso de enseñanza-aprendizaje en las escuelas y desarrollo de las «competencias para la participación perdurable en la cultura movimiento» un nombre general para los resultados deseados. Objetivos de la «enseñanza del movimiento y el deporte « son especificados y formulados en términos de aprendizaje afectivo (aprender a ser activo, para jugar, para participar en el deporte), aprendizaje technomotor, aprendizaje sociomotriz y el aprendizaje cognitivo / reflexivo. A continuación se discute la visión sobre el movimiento humano. A continuación se discute la visión del movimiento humano. Debido a su productividad educativa, se recomienda una visión «relacional» del cuerpo y una visión «relacional» del movimiento humano en lugar de la visión tradicional del cuerpo y la visión newtoniana del movimiento. La enseñanza del movimiento y el deporte no trata del físico, del cuerpo como una máquina, sino de los niños que se mueven y enseñarles cómo moverse, enseñando cómo resolver los problemas de movimiento. En consonancia con este punto de vista, se elaboran dos principios didácticos: 1) orientación hacia el problema y 2) orientación al estudiante. El último párrafo contiene un argumento a favor del currículo «ecológico» y de la apertura institucional.

Palabras clave: Crisis de identidad del PE, fracaso de las ideologías tradicionales, cambio de paradigma, justificación como asignatura escolar, objetivos, visión del movimiento, orientación a los problemas, orientación estudiantil, currículo ecológico.

(Footnote)

${ }^{1}$ Warning for the reader: When I received Francisco Carreiro da Costa's invitation to deliver «a conceptual paper» for this RETOS issue, I replied saying that I - as a long time ago retired scholar - did not feel capable to come up with an original paper and that the only thing I could offer him was an assemblage by using parts of earlier papers and presentations; e.g. Crum (2007) and Crum (2012). Then Carreiro da Costa requested to provide him with such a paper. Consequently readers might meet text parts that they already know. 


\section{A brief description of the current misery}

Together, the general dissatisfaction with the outcomes of schooling and economic problems continuously caused and cause severe cuts in the budgets for education. This seems to be a world-wide phenomenon. Consequently the call for accountability in the educational system has increasingly become louder. Under such conditions, teachers are a convenient target for criticism and when teacher quality is at stake, inevitably the quality of teacher education will also be at stake. These challenges affect all school subjects, but by comparison to most other school subjects, physical education (PE) in particular has to endure greater scrutiny. Apart from the dissatisfaction with its outcomes and the criticism on the quality of PE teacher education (PETE), PE must also cope with serious skepticism concerning its social relevance.

In the early summer of 2016 the Board of the Royal Dutch PE Teacher Association challenged its membership with an alarming question: «Will PE in 2032 still exist as a school subject?» The immediate reason for this question is the fact that in the final report of a governmental advisory committee concerning the desirable structure and content of Dutch school education in $2032 \mathrm{PE}$ no longer mentioned PE as a subject in the core curriculum. On the one hand, a rather surprising development since PE, after a critical stage in the 1980ties, seemed to be firmly embedded in Dutch school education. On the other hand, this decision was not fully unexpected because as far as I can remember in many countries $\mathrm{PE}$ has been put in the black books again and again.

That PE sails on a turbulent sea and must cope with legitimization pressure has been going on for a long time. Almost 50 years ago the German sport pedagogue Konrad Paschen wrote about the «SchulsportMisere» (1969). Some 25 years ago the USA scholar Larry Locke made the following critical statement: «If PE is to have a significant presence in the secondary schools of the $21^{\text {st }}$ century, it is better to chuck the dominant model and start over from scratch» (1992, p. 362) Also, in 1993 I concluded that PE suffers from a serious identity crisis (Crum, 1993a). In the $21^{\text {st }}$ century - in particular after the Berlin World Summit of PE (1999) - a choir of plaintive and warning voices could be heard. I will forgo the details and confine myself to a series of catchwords which are largely extracted from the worldwide survey by Hardman \& Marshall (2000), the comparative study by Pühse \& Gerber (2006) and a report for the European Union by Ken Hardman (2007).

Although there are substantial differences between countries (there are even some countries where PE is flourishing and on the rise), the following problems and deficiencies have been observed in many countries around the world:

- low status of the subject

- decline and marginalization

- reduction of curriculum time

- neglect of PE in primary education

- poor conditions / facilities

- lack of teacher competence

- low standard of programs

- weak PETE programs

- discrepancy between curriculum as text and curriculum in action - credibility gap.

The above listed issues are doubtlessly interrelated. Nevertheless it makes sense to distinguish between problems which have rather a political-financial character (e.g. reduction of time, neglect of PE in primary education, poor facilities) and problems which are due to the lack of quality of the PE profession itself. Tackling the first category demands political lobbying by national and international PE teachers' organizations, while the second category requires first and foremost theorizing and research by sport pedagogy scholars in order to reveal the causes of the deficiencies as well as serious efforts to improve the quality of PE and PETE practices.

\section{A more precise diagnosis of the quality problems}

About 30 years ago I asked about 1000 Dutch PETE students to try to remember the character of the PE lessons they got in secondary school. Then I asked them to look to the following four profiles of PE classes - each represented by a few keywords:

(1) exercise-sweat-fitness

(2) fun-pleasure-entertainment

(3) control-order-discipline

(4) relevant learning concerning movement and sport

Next I asked them to make a choice from these four options. Which one forms the best characterization of your secondary school PE classes? Who votes for number (1)? Who for (2)? Who for (3)? Who for (4)? In my view the outcomes of the voting were alarming. $40 \%$ voted for «fun - pleasure-entertainment», 30\% for «exercise-sweat-fitness», $10 \%$ for «control - order - discipline» and only $20 \%$ for «relevant learning concerning movement and sport». Only $20 \%$ of the students had experienced physical educators who had profiled themselves as teachers, $80 \%$, by far the majority, had been confronted with models which were rather entertainers (fun), fitness trainers (sweat) or drill sergeants (control). Over the last two decades, I routinely started my conference presentations or guest lectures abroad with the same investigation. Most of the time the outcomes were more alarming than those of the investigation conducted with Dutch PETE students. The voting percentage for «relevant learning» never passed $10 \%$ and in all cases «fun» and «sweat» together came up to $80 \%$. Polling outcomes in Japan (Tokyo and Nara, 2008) and Czech Republic (Ostrava, 2007) formed a remarkable exception since «control - order - discipline» scored as high as $40 \%$.

The outcomes of these unofficial investigations gave me reason enough to assume that the essential problem in the PE profession is not primarily that there is bad teaching (with lack of time on task, direct instruction, appropriate feedback, accountability, etc.). The situation is much more precarious. The point is «that the community of physical educators, in the cosmology of its professional values, does not unanimously accept and give priority to the proposition that a physical educators' primary function is to help pupils learn» (Locke, 1987, p. 5). Many physical educators, perhaps even the majority, are not really committed or motivated to 'teaching' as the essential of the physical education enterprise. The term 'teaching' is often carelessly and mindlessly used in association with PE. Many physical educators speak about 'teaching PE' without any evidence of an intention to produce learning. Consequently this absence of a real commitment to teaching among physical educators has resulted in a general lack of learning in PE classes. PE in the reality of our public schools does not achieve the profile of a relevant teaching-learning activity and therefore the basis for support will be further eroded.

I assume that the precarious situation of the PE profession can, at least partly, be explained by the ideological legacy of the profession. Two longstanding PE ideologies, which were constructed in order to gain «therespect and recognition of the educational world» (cp. Siedentop, 1983, p. 47), still negatively influence and retard the perspectives of physical educators and their practices in school, either in an open or in a more subcutaneous way. The first ideology has its roots in biological reductionism and can be qualified as a 'biologistic ideology'. Its origins lie in the system of the Swedish gymnastics. Per Henrik Ling, and in particular his son Hjalmar Ling, viewed the development of the bodyinstrument by means of well-chosen movements as the objective of this system. At the end of the nineteenth century the Swedish system took roots in West Europe as well as in North America. Of course, under influence of changing scientific insights and also due to developments in the panorama of diseases the original ideas were adapted from time to time. However, the basic idea remained the same. It is the idea that the human body is a machine, an instrument, and that movement-exercises can improve the status of the body-machine. PE is seen as 'training-ofthe-physical', and thus important in view of the threats of diseases (tuberculosis in former days, then coronary diseases and obesity nowadays). PE programs based on this concept have the following characteristics:

- the objectives are formulated in terms of training effects 
(improvement of cardiovascular endurance, flexibility, muscle power, etc.);

- content description is in terms of training exercises (often classified according to body parts);

- the main methodological principle is: keep them busy with a high level of exertion and frequent repetitions of simple exercises;

- pupil tasks are formulated as training tasks (that are tasks directed to biological adaptation of the body-machine) rather than as learning tasks (that are tasks directed to enlargement of competence).

Under the influence of this idea $\boldsymbol{P E}$ easily degenerates into $\boldsymbol{P A}$ (physical activity).

The second ideology has its roots in pedagogical idealism and can be qualified as a 'pedagologistic ideology'. West Europeans can think of the influence of the Philantropinism and of the German and Austrian «bildungstheoretische» school of thought. In NorthAmericathis ideology of 'education-through-the-physical' begun with authors such as Thomas Wood and Clark Hetherington. The basic assumption here is that movement is an outstanding medium for exploration, communication, general personal development and character building. The adherents of this ideology believe that movement-in particular the traditional canon of gymnastics, play and dance-has a special potential for the cognitive, aesthetic, social and volitive development of youngsters. In this view the essential of PE is not 'learning to move' but 'moving in order to learn and to get educated'. Consequently objectives are formulated in rather abstract, 'pie in the sky' terms. Often the idea of a 'functional education' is striking. This idea claims that educational effects come automatically just by taking part in the movement activities with the ascribed high educational potential. This assumption has seduced and continues to seduce many physical educators into thinking that intentional teaching is superfluous, that their task is just to organize the activities with the assumed intrinsic educational potential in an orderly way and in a nice atmosphere. Under influence of this idea PE classes easily degenerate into entertaining breaks of the learning-oriented school day.

First and foremost, the two ideologies are essentially different in their fundamental assumptions concerning the body, movement, children and education. However, they display also noticeable similarities. The following points are noteworthy:

- Both conceptions are based on a body-mind dualism.

- In both conceptions movement is not the objective but the means of the intervention act. In the first case movement is used as a mean for body building and body shaping, in the second case movement is used as a mean for character building and personality shaping. - In both conceptions the idea of 'compensation' is predominant. In the first case compensation of the lack of movement in everyday school life, in the second case compensation of the lack of 'real education' in the basic teaching-learning subjects.

- Both were constructed during PE’s struggle for public recognition. As such both are characterized by strong rhetoric and pretentious claims for outcomes. Even though evidence shows that these claims cannot be substantiated under school conditions (see e.g. Brettschneider, 2007; Evans, 2003; Evans, Rich \& Davies, 2004), the PE profession still returns to fitness and character building whenever it is called to justify itself by public opinion.

-Both conceptions inducenon-teaching PE practices. Thebiologistic ideology leads to PE as fitness training. The pedagologistic ideology easily leads to PE classes that have the character of supervised recess or entertainment.

The two ideologies are still widely proliferated in our profession. They have a strong impact on many official curriculum documents. They influence the professional perspectives of physical educators and of PETE faculty, and moreover they determine the public opinion concerning the task of PE. I assume that the combined influence of the two conventional ideologies forms the cement in the vicious circular model of what I have called 'the theory of the self-reproducing failure of PE'(Crum, 1993b) ${ }^{1}$. An important factor in this theory is the assumption that many PETE programs are too weak (because PETE faculty don't have a common PE perspective and don't share a technical culture) to rectify what has been experienced during 'the apprenticeship of observation' (Lortie, 1975). In this 12 years long period many PETE students might have 'learned' that PE is more about 'entertainment' or/ and 'fitness training' than about teaching-learning.

In summary: It is undisputed that the traditional ideologies (that have been or are still leading our field all over the world) fail because they:

- don't achieve the outcomes that they promise (there is enough empirical evidence that it is impossible to substantially develop character or to improve physical fitness under the conditions of school PE - think e.g. of the limited time budget and the large and heterogeneous student groups),

- have led practitioners to non-teaching PE practices (the 'educationthrough-the-physical' ideology failed to provide teachers with methodical tools and caused physical education classes with the character of entertainment or supervised recreation - the 'trainingof-the-physical' ideology has led to PE classes in which fitness training is central instead of teaching and learning),

- have lost their credibility (because the outcome claims could never been substantiated),

- have caused the risk that the subject will be deleted from the school curriculum (in many countries PE has a very low status and in many countries educational authorities again and again come with the idea to delete PE as a school subject).

With respect to the position of PE as a school subject the situation has become threatening since it appears that the old rhetoric ( $« \mathrm{PE}$ is indispensable for fitness and health» or «PE is indispensable for character development» has lost its persuasiveness. Therefore PE communities are now looking for alternative lifebuoys. In the last 10 years or so the assumption that physical activity enhances the cognitive development and academic performance of children and youngsters is increasingly used as an argument for establishing or keeping PE as a mandatory subject in the curriculum. I'm afraid that firstly, there is a lack of empirical evidence in favour of the underlying assumption (see, Singh et al, 2012 and Singh, 2015). Moreover, the fact that the assumption is rather an argument for physical activity than for physical education this line of argument will ultimately hit the PE community like a boomerang.

It may be obvious, in order to save $\mathrm{PE}^{2}$ as a part of the school curriculum, the profession needs a new paradigm. We need a new view, a new way of theoretical thinking and a new way of acting in practice. In trying to outline the main characteristics of a new paradigm, that is plausible as well as fruitful, I will briefly (may be sometimes too briefly) discuss the following issues: (a) justification as a school subject, (b) objectives of 'teaching movement and sport' (c) view of human movement, (d) didactical principles and (e) an 'ecological' curriculum and institutional openness.

\section{Justification of 'movement and sport' as a school subject}

One of my starting assumptions is, that school subjects trying to claim a position in the core curriculum on the basis of their assumed formal educational effects (e.g. contribution to character building, logical thinking, social formation) will fail in the struggle for survival. The idea, that there are two types of school subjects - one in which cultural skills necessary for participation in society are transmitted, and another in which formal education is the focus (which is often claimed for subjects such as Art and PE) - is no longer tenable. Schools only have room for subjects in which relevant skills and knowledge can be taught in a way that also fosters the desirable formal education. The relevance of school subjects should be judged by their utility value, the extent to which social preparation and formal education interact and reinforce one another. In the face of competing claims on school time by various subjects, the school should concentrate on those curricula that (a) are emancipating because they prepare youngsters for a relevant, humane and independent participation in social-cultural life; (b) can be fulfilled according to the typical institutional status of the school, and (c) cannot be fulfilled 
better by other socialization agencies.

In looking for a rationale and foundation for $\mathrm{PE}$ as part of the school curriculum, I relied on the aforementioned three criteria. Space is too limited here for an extensive explanation, so I will summarize my line of thinking by briefly explaining three pertinent theses.

Thesis 1: In modern societies participation in movement culture contributes to the quality of life of many of its members. First, a few words about the term 'movement culture', which is not common in the English language, are necessary to avoid misunderstanding. Generally the 'culture' concept refers to configurations of values, beliefs, conventions, rules of conduct, understandings, knowledge and skills. For example, the specific way in which a group of people deals with the issue of house design and construction can be labeled as a 'housing culture'. Similarly, one can speak of a 'teaching culture' and of a 'movement culture'. Movement culture, as it is generally used in the German and the Dutch languages, refers to the way in which a social group deals with the issue of corporeality and embodiment and the need and desire for movement beyond labor or life maintenance. Movement culture contains the set of movement actions and interactions (sport, play, dance, or other fitness activities) that encompass a group's leisure time.

The term 'movement culture' emphasizes that exercise, play and sport are more than just physical activity and that these activities are governed by rules and are changeable. Moreover, the term has a much wider scope than the concept of sport. Movement cultures vary dependent on time and place. Mainly in reaction to the disdain for the flesh under Christian traditions and the denial of corporeality under the influence of modern labor and transport technologies, most modern societies today display a differentiated movement-cultural domain. Up until the 1960s the movement-culture mode of competitive sport was dominant. That was a meritocratic mode, because only the vital, competitive, skilled individual could feel at home in it. However, in the past fifty years sport has differentiated into a multifaceted movement culture. This multifaceted character has implications for the movement activity as such, but also for the motives for participation, the characteristics of participants, the rules of conduct and the degree of organization. For many people in our societies 'doing sports' - or better, 'participation in movement culture' - has become a self-evident and highly valued aspect of daily life. Participation in movement culture allow them to realize and experience important values, such as recreation, health, adventure, excitement, togetherness, performance and selfrealization.

Thesis 2: A lasting and satisfying participation in movement culture demands a repertoire of competencies that does not come automatically to people but requires organized teaching-learning processes. Subjective competency experiences are important conditions for life-time participation in movement culture. For such a satisfying and lasting participation, one must develop a repertoire of skills and knowledge so that exercising, playing, dancing or sporting is possible without disgracing oneself and/or disturbing other participants. An analytical approach of the needed repertoire elicits the following classification of competencies:

- Technomotor competence - for example: the skill to catch a ball, to pass an opponent, to swim across the water, to move according to the rhythm of the music

- Sociomotor competence - for example: the ability to win or lose, to accept the talents and shortcomings of oneself and also those of teammates, and to know oneself as a player or dancer and have empathy for the play-, dance-, or sport-identity of others

- Practical knowledge and reflective competence - for example: knowledge of the relationship between exercise and fitness and understanding of conventions and rules as well as the possibilities of adapting rules to changing needs.

Such a competency repertoire does not comenaturally to individuals; it can only be acquired in structured learning processes.

Thesis 3: Since every youngster goes to school for at least 12 years and since schools are provided with professional teachers, the responsibility for the introduction into movement culture should be in the hands of the school. It should be admitted that the schools do not have a monopoly on cultural introduction, especially not when the introduction into movement culture is at stake. Sport clubs (Europe), community sports programs (North America), special sport schools, fitness centers, swimming pools, dance studios offer a wide range of opportunities to acquire movement skills and sport knowledge. Moreover, our society is 'blessed' with a media system that works as a powerful sport socializer. However, starting from the assumption that it is desirable that all youngsters get a chance to become familiar with a variety of aspects of the movement culture and to acquire the competencies needed for a lasting participation, it seems obvious that the school must play a central role in the movement socialization process. Two considerations are especially relevant. First, only a limited part of the youngsters find the door to a sport club or other agency with a sport supply. This is especially difficult for students who come from disadvantaged economic and/or cultural backgrounds. However, all youngsters go to school and take part in PE classes for at least 12 years. Second, although it should be acknowledged that sport clubs and other agencies may educate, this is not their main intention. Generally the experiences, which can be collected in the context of those agencies are colored by typical self-interest objectives and various limitations. A sport club, for example, concentrates on only a few sport disciplines and generally emphasizes more immediate goals with an orientation toward competition.

\section{Objectives of teaching movement and sport}

What are the objectives (the desirable outcomes) of teaching movement and sport? On a more abstract level the general objective can be formulated as follows: On the one hand giving students opportunities to develop a personal movement identity and on the other hand introduction into movement culture in such a way that students can acquire the competencies needed for a self-reliant, sensible, lasting and satisfying participation in movement culture. It is about personal development and about development of social competencies as two sides of the same coin. Learning outcomes should have utility value and relevance for the students for now and later in their lives.

Then, on a more concrete level, the desirable outcomes can be specified as follows:

- development of a personal movement identity,

- development of a positive bond with exercise, play, sport and dance (if you don't learn to like it you will never develop an active life style) - I label this as affective learning,

- competence in solving technomotor problems - these are movement problems in the narrow sense; e.g.: to catch a ball, to close or to open a passing line, to serve a tennis ball, to jump across an obstacle, to run a specific distance, to dive into the water, to swim across the water, etc. - here technomotor learning is the goal, - competence in solving sociomotor problems - these are interpersonal problems that are inherent to movement and sport situations; think for example of how to deal with winning and losing, to know oneself as a player or dancer while having empathy for the sport identity of others, to accept help from others and to give help - I label this as sociomotor learning,

- enhancement of knowledge and reflective capacity which are needed to organize and rule one's own exercise and sport activities (examples: knowledge and reflective capacity to solve a rule problem or to organize a school tournament or to plan an exercise program for the improvement of one's own endurance capacity) - here cognitive-reflective learning is the goal,

- enrichment of the school life (especially through organizing extracurricular activities).

A few words in reference to Figure 1 about the interrelationships of the learning domains. When teaching students to learn to solve movement problems the teacher can switch his/her focus. Let us take teaching basketball as an example. In a particular part of a lesson or even in a 
particular series of lessons, the focus can be on learning how to dribble and how to score with a lay-up shot. Then the focus is on techno-motor learning. In another part of the lesson or in another series of lessons the focus can be on how to play together in a heterogeneous group, how to give more or less equal opportunities to all students. Then the main issue is sociomotor learning. Switching the focus requires changes in problem setting, in instructions and in feedback and for example also in the grouping of students. When playing basketball in a heterogeneous group, the teacher can stop the game and during the time-out he can ask questions. For example «how does it come that John always tries to score and that Donald did not even get a chance? Can we introduce a rule that makes that both have more or less the same opportunity?» In doing so the teacher puts the focus on cognitive-reflective learning. Finally the figure shows that affective learning is the basis for all other learning. If the students don't feel physically and socially safe, if there is no good interaction between teacher and students, if students don't enjoy participating in the activity, then there will be no affective learning and then the chance for the other learning domains will be severely reduced.

\section{Learning to solve movement problems}

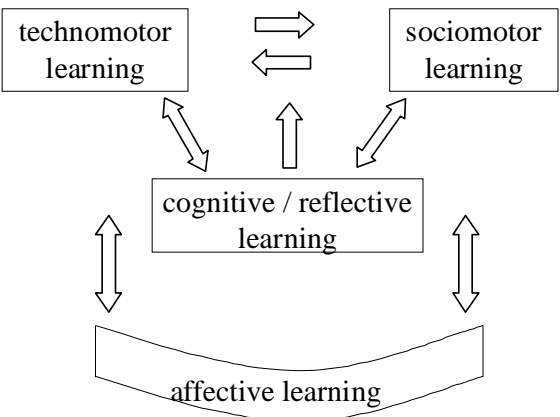

Figure 1: interrelationships between learning domains in teaching movement \& sport

I view 'planned introduction into movement culture' as an appropriate label for the desirable process in public schools and 'competencies for lasting participation in movement culture' as a general label for the desired outcomes. By doing so I emphasize the importance of teaching and learning. This emphasis could possibly produce misinterpretations. Physical educators could get the idea that teaching movement and sport, as the traditional academic school subjects, is only concerned with serious learning and preparation for later participation. That would be a misunderstanding. Although the lessons should be designed in view of learning with utility value, they should also offer opportunities for exciting and joyful experiences in the here and now. The obligatory classes and the optional school sport activities should be arranged to realize both aspects. Yet the arrangement of PE classes as real teaching-learning activities constitutes the heart of the profession. Only by holding sport and play at arm's length can pupils transcend beyond the level of just doing exercise or sport or play. Only by learning that sport is a constructed activity can they understand what movement culture is and eventually how to change the conventions and rules which govern it.

In order to give you a more concrete idea, I present some examples of how objectives are formulated in a Dutch curriculum document (SLO, 2007 - the SLO is the Dutch Foundation for Curriculum development). The examples are from the activity domain «games» for the lower secondary level (age 13/14).

- students know how to play a batting / running game (e.g. softball); they can:

bring a ball into play by batting (a technomotor problem),

as a base runner, stay in play by making correct start and stop decisions (technomotor problem),

as a fielder, catch a hit or thrown ball (technomotor problem).

- students know how to play three invasion games (e.g. soccer, field hockey, handball, korfball, basketball); they can: when their side has ball possession, set up an attack with their team mates (a technomotor as well as a sociomotor problem), together with team mates set up a defense and avoid scores of the other side (a technomotor as well as a sociomotor problem).

- students are able to execute tasks that enable them to play together; they can:

play a game, either as winner or loser, with respects for the opponent(s) (sociomotor problem),

adapt situations and rules to the level and wishes of the group (sociomotor and cognitive-reflective).

\section{View of human movement}

This issue must be discussed because it has important repercussions for teaching methods. There are different views of movement. Different lenses or glasses can be used to view and interpret human movement. It is like using different maps when traveling through the countryside. If you plan to travel by foot you will use another type of map than when you are going to travel by car. Back to human movement. An orthopedic surgeon who prepares knee surgery will start from a view of movement in which biomechanics is essential. However, for teaching 'movement and sport' another view might be more productive. In the following schematic I present two views of the human body and two views of human movement (cp. Tamboer, 1985).

\section{views of the body / human movement}

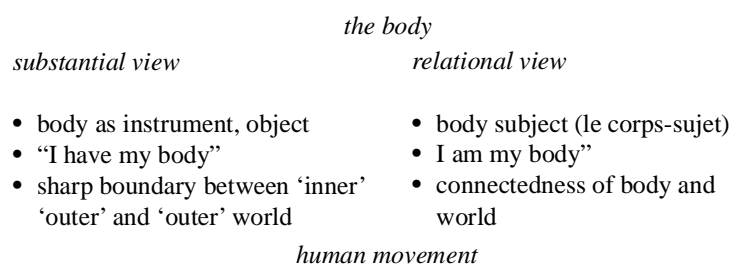

'Newtonian'view relational view

- movement as spatio-temporal - movement as a way of displacements of (parts of) the body $\bullet$ knowing the world in action

- exercises: bending an arm, - activity verbs: swimming, stretching the back, turning the - throwing, catching, etc. head, etc.

I emphasize that this is not to say that one view is correct and that the other one is incorrect. The views are not mutually exclusive. However, I underline that one of the views - the 'relational' view - is more fruitful for educational purposes, for the case of teaching movement and sport. I assume that you are familiar with the substantial and the Newtonian views. In your study to become a physical educator the lenses of anatomy, physiology and biomechanics have probably been dominant. Then you have learned to see the body as an instrument, as a machine that should be kept in good condition. Then you have learned to see the body as a thing that you have, not as the body-subject that you are. Then you have learned to see movements as displacements of body-parts in time and space, not as a 'dialogue' between a moving person and a world that invites to move, that challenges to move. For a medical doctor or a surgeon or a fitness trainer the substantial view of the body and the 'Newtonian' view of human movement are very appropriate and useful. However, I think that for education, for teaching movement and sport, the 'relational' view is more useful and productive. This is not to say that e.g. information from biomechanics or other natural sciences is not important. Certainly it is relevant. However, that kind of information should be integrated in the wider perspective of the 'relational' view. I invite the reader to accept new lenses, to take another pair of glasses than you have been used to. Then you can see and interpret human movement:

- as a 'dialogue' of a moving person with an environment that invites to move (Gordijn, 1958; Reed, 1982); this can be labeled as 
an 'ecological perspective’,

- as meaningful behavior, as 'action' based on intentions and rules,

- not as meaningless (de-contextualized) displacements of (parts

of) the body, but as meaningful changes in the relationship between a moving person and his/her environment,

On the basis of this view you can see learning to catch a ball or to swim across the lake or ......., not as learning to make specific displacements of the arms / legs in 3-dimensional space, but as learning to solve a specific environmental problem (see e.g. Reed, 1988). In the past decades the ecological psychology has produced a lot of empirical evidence in support of this view (see e.g. Renshaw et al, (2010) and Wulf (2007)). This evidence has important consequences for motor learning theory and for teaching movement and sport ${ }^{4}$.

On the basis of these views of the body and human movement you will understand that our school subject is not about the physical, the body-machine, but about moving children and teaching to move, teaching how to solve movement problems. Then it will become clear for you that the main mission of our subject is to introduce youngsters into the world of motor meanings, to make movement situations habitable for the students. Then you will accept that the general objective of teaching movement and sport is: helping all students to acquire the essential skills, knowledge and attitudes that are needed to participate competently in movement culture. Summarizing I repeat:

- it is not about the physical, the body machine, but about moving children and teaching to move, teaching how to solve movement problems,

- the mission of our subject is: to introduce youngsters into the world of motor meanings; to make movement situations habitable for students,

- the objective of teaching 'movement and sport' is: all students acquire the essential skills, knowledge and attitudes that enable them to participate competently (in a lasting, responsible and autonomous way) in movement culture.

\section{Didactical principles}

How should lessons in movement and sport be arranged in order to realize the formulated objectives? In answering this question I elaborate two didactical principles. First, problem orientation, and second student orientation.

The main idea of problem orientation is that the teaching-learning process is centered around a movement problem and not around a solution (think e.g. of a specific movement technique). Often physical educators are inclined to start their teaching with the solution, e.g. a specific technique to catch a ball or to jump across a bar. In presenting the solution from the very beginning, teachers try to mold all students into the direction of the same technique. I plea for a contrasting approach: starting from a clear set movement problem and then helping students to learn how to solve that problem. Long ago Confucius confronted us with an important wisdom: «Tell me and I will forget. Show me and I may remember. Involve me and I will understand». This quote clearly underlines the importance of involving students in learning to solve problems. I present the following concrete indications for problem orientation:

- organize the teaching-learning process on the basis of a clear definition of the central movement problem (e.g. in teaching handbal a central movement problem could be: ‘opening passing lines' and 'closing passing lines') ${ }^{5}$,

- set the learning task in terms of learning to solve a movement problem (it happens too often in PE classes that there is no clear learning task; then the teacher gives students the idea that it is enough only to move around, to be active),

- structure the learning environment (e.g. by grouping of students and by arrangement of equipment) in such a way that the main movement problem can be recognized, understood and experienced by the students,

- provide the students with extra information by changing/modifying the learning context (e.g. changing the size of a ball, changing the size of a goal, changing the pitch, changing the length of a swinging rope, changing the distance between springboard and vaulting horse - I

label this principle as 'landscaping'; external focus of attention is the underlying idea).

The second didactical principle is student orientation. Teaching should be centered around the learners and not around the teachers. I give the following concrete indicators for student orientation:

- recognize and accept the individuality of each student (movement identity as well as learner identity),

- give the students responsibility for their own learning (of course this should be done in relation with the growing age of students the 'division of power' between teacher and students should gradually change),

- involve the students in planning, organization and evaluation of the teaching-learning process,

- stimulate the students to reflect on the movement problem to be solved as well as on their own learning process and progress.

In conclusion I present the following methodical 'rules of thumb': - arrange clear learning situations (so not training / sweating or entertainment/fun situations),

- set clear learning tasks,

- use 'scaffolding'; that is: give structure and support; for example by clarifying or restructuring the learning task or by reducing / increasing the level of complexity,

- use 'landscaping' as a form of scaffolding,

- avoid instructions that focus on body parts, but give instructions in terms of time / timing (earlier / later), tempo (faster / slower) and direction (to the ceiling / downwards; to the right / left). Doing so the external focus of attention of the students will be stimulated ${ }^{6}$.

\section{7. 'Ecological' curricula and institutional openness}

Long ago Daryl Siedentop warned that teaching-learning processes in which sport is «hold on arm's length create the risk of decontextualization, which includes the risk of a deterioration of play and sport, including boredom and lack of interest» (Siedentop, 1987). A few years later Tinning \& Fitzclarence (1992) sounded the same alarm by stating that they observed considerable discrepancies between what is going on in PE classes and what is going on in the movement culture of youngsters outside the school. It appears that this problem is also manifest in European schools since about 10 years ago the same conclusions have been drawn by Gerlach et al (2006) and Hardman (2007). Generally speaking, the complaint is that the traditional content of PE classes has little relevance for the students and does not fit with their life-styles.

An important trick of the trade is to ensure not to neglect the pleasure and the joy in the scheduled and learning-oriented classes, while making sure that optional school sports provides opportunities for relevant learning besides the elements of excitement, fun, celebration, competition and achievement. Moreover, in my view it is of vital importance, especially for students of 15 years and older, to overcome the stifling de-contextualization of their PE movement experiences by breaking the restrictions of the traditional time table, the old-fashioned equipment in the gym $^{7}$ and the compulsory grouping of students according to their grades. I think it is high time to respond to changes in the movement culture and in the needs of youngsters. Assuming that a longitudinal PE curriculum in primary school and the lower grades of secondary school has laid a firm basis of 'movement vocabulary' and 'movement grammar', I recommend beginning the development of what I label as an 'ecological' movement and sport program for students beyond the age of 15. I emphasize that the keyword for an ecological program is 'relevance' and certainly not just fun (for the students).

An ecological PE program is characterized by the following elements: - inclusiveness, whichmeans that it provides to each student chances for relevant learning; thus it is not only performance oriented; - students are obliged to choose out of a number of thematic options; 
for example: 'physical activity, health and fitness' or 'games, competition and cooperation' or 'nature sports, challenge and adventure';

- learning experiences are presented in thematic units and relatively long time units (e.g. a whole afternoon or a project week);

- the learning experiences are as much as possible provided in real settings (qua facilities as well as qua staging);

- utility value (relevance) for present and future of the students; - content is culturally and contextually embedded;

- institutional openness, which means that the PE department of a school strives for cooperation with sport providers in the direct environment and with community work agencies;

- students have a substantial share in the planning, organization and evaluation of programs;

- the sport specific know-how of particular students is intentionally and intensively used.

Being aware of the fact that the realization of an ecological PE program requires, at least partly, a substantial de-schooling of PE, I am convinced that only ecological programs can expel the decontextualization and the related 'de-motivating' conditions, which are so typical for traditional programs.

My final issue: institutional openness. It was Seneca who said: «Non scholae sed vitae discimus». In translation: we don't teach for the school, we teach for life. Well, if we want teaching movement and sport to be a bridge for the students towards participation in the movement culture outside the school, schools (and within schools the departments of PE) should be agencies with open doors and open windows to the community in which they function. PE departments should strive for cooperation with sport clubs, swimming pools and fitness centers in the community. Especially for planning and arranging a rich school sport program they should use the expertise and opportunities that are available in these non-school agencies. In doing so, the school should be aware that the pedagogical responsibility remains in the hands of the school. The interests of organized sports (clubs) or of the commercial sport agencies can be at odds with the interests of the students. It is selfevident that the school keeps a critical stance in the relationship with the sport agencies and in case of a conflict of interest always takes the side of the student(s).

In closing, I implore you to remember that a rich and well-balanced extra-curricular school sport program forms an appropriate supplement and support for an ecological curriculum. It is not only an enrichment of the life at school and a treat for many students, but also very instrumental for the PE department.

\section{Acknowledgement}

I thank dr. Gary T. Barrette for his assistance in editing this paper.

\section{References}

Brettschneider, W.-D. (2007). Mozart macht schlau und Sport bessere Menschen. Transfereffekte musikalischer Betätigung und sportlicher Aktivität zwischen Wunsch und Wirklichkeit. Paper Tagung DVS Sektion Sportpädagogik, Augsburg Juni 2007.

Carreiro da Costa, F. (2010). Educar para una Vida Activa: Cómo Superar la Situación Paradójica por la que pasa la Educación Física en el Contexto Internacional. Cagigal Lecture at AIESEP World Congress, La Coruna 2010.

Crum, B.J. (1993a). A Crise de Identitade da Educação Fisica - Ensinar ou não Ser eis a Questão. Boletim SPEF, 7/8, 133-148.

Crum, B.J. (1993b). Conventional Thought and Practice in Physical Education: Problems of Teaching and Implications for Change. QUEST, 45(3), 339-356.

Crum, B.J. (2007). How to pave the road to a better future for physical education. In J. Tolleneer, M. Lenoir, W. Laporte (Eds.), 100 years of Physical Education and Movement Sciences at Ghent University: Academic Session, (pp. 47-72) Innovex : Gent.

Crum, B.J. (2012). La crisis de identidad da la Educación Física. Diagnosis and explanation. Educación Física y Ciencía, Ano 14: 61-72. Universidad National de La Plata, Argentina.

Evans, J. (2003). Physical education and health: A polemic, or, let them eat cake! European Physical Education Review, 9, 87-103.

Evans, J. Rich, E, \& Davies, B. (2004). The Emperor's New Clothes: Fat, Thin, and Overweight. The Social Fabrication of Risk and Ill Health. Journal of Teaching in Physical Education, 23, 372- 391.
Gerlach, E, Kussin, U, Brandl-Bredenbeck, H.P. \& Brettschneider, W.-D. (2006). Der Sportunterricht aus Schülerperspektive. In: DSB (Hrsg), DSB-SprintStudie, (pp. 115-152). Aachen: Meyer \& Meyer.

Gordijn, C.C.F. (1958). Bewegingsonderwijs in het onderwijs- en opvoedingstotaal (Teaching movement within the general frame of education and teaching). Kampen: Kok.

Hardman, K. \& Marshall, J. J. (2000). Worldwide survey of the state of school physical education, Final report. Manchester: University of Manchester.

Hardman, K. (2007). Current situation and prospects for physical education in the European Union. Report for the Directorate General Internal Policies of the Union. Brussels.

Locke, L.F. (1987). Research and the improvement of teaching: The professor as the problem. In: GT. Barrette, R.S. Feingold (Eds.), Myths, Models, Methods in Sport Pedagogy (pp. 1-26). Champaign, IL: Human Kinetics.

Locke, L.F. (1992). Changing secondary school physical education. Quest, 44, 361372.

Lortie, D. (1975). Schoolteacher: A sociological study. Chicago: University of Chicago Press.

Paschen, K. (1969). Die Schulsport-Misere. Braunschweig: Westermann Verlag.

Pühse, U. \& Gerber, M. (eds.) (2006). International Comparison of Physical Education: Concepts - Problems - Prospects. Aachen: Meyer \& Meyer.

Reed, E.S. (1982). An outline of a theory of action systems. Journal of Motor Behavior, 14, 98-134.

Reed, E.S. (1988). Applying the theory of action systems to the study of motor skills. In: O.G. Meijer \& K. Roth (Eds.), Complex movement behaviour: The motor-action controversy. (pp. 45-86). North-Holland: Amsterdam.

Renshaw, I. et al (2010). A constraints-led perspective to understanding skill acquisition and game play: A basis for integration of motor learning theory and physical education praxis? Physical Education \& Sport Pedagogy, 15 (2), 117-137.

Siedentop, D. (1983). Physical Education; introductory analysis. Dubuque: Brown.

Siedentop, D. (1987). The theory and practice of Sport Education. In GT. Barrette \& R.S. Feingold (Eds.), Myths, Models, and Methods in Sport Pedagogy (pp. 79-86). Champaign: Human Kinetics.

SLO (2007). Basisdocument Bewegingsonderwijs voor de Onderbouw van het VO (Manual Teaching Movement and Sport for Lower Secondary Education). Zeist: Jan Luiting Fonds.

Singh, A. et al (2012). Physical Activity and Performance at School - a systematic review of literature including a methodological quality assessment. Archives of Pediatric and Adolescent Medicine. 166 (1), 49-55.

Singh, A. (2015). Physical Activity and Academic Performance - State of the art in Youth. Keynote AIESEP Congress, Madrid, July 2015.

Tamboer, J.W.I. (1985). Mensbeelden achter Bewegingsbeelden (Views of Human Beings under Views of Movement). Haarlem: De Vrieseborch

Tinning, R. \& Fitzclarence, L. (1992). Postmodern Youth Culture and the Crisis in Australian Secondary School Physical Education. Quest, 44, 3.

Thorpe, R., Bunker, D. \& Almond, L. (Eds) (1986). Rethinking games teaching. Loughborough: University of Technology.

Wulf, G. (2007). Attention and Motor Skill Learning. Champaign, IL: Human Kinetics.

(Notes)

${ }^{1}$ See Carreiro da Costa (2010) for an explanation of the vicious circle model in Spanish.

${ }^{2}$ In The Netherlands the tendency is growing to use '(teaching) movement and sport' as label for our subject. The main reason s are that we want to underline the teaching mission of the subject and to avoid the dualist connotation of the term 'physical education'.

${ }^{3}$ In the SLO curriculum document the movement activities to be taught are classified according to movement problems. Related problems are brought together in «activity domains». The following domains are distinguished: (1) apparatus gymnastics (balancing, jumping, swinging and climbing); (2) (sport) games (tag and batting games, invasion games, return games); (3) track and field (running, jumping, throwing); (4) rhythm and movement (dances). These domains are taught in primary as well as in secondary education. Moreover in secondary education there is a $5^{\text {th }}$ domain, especially for girls: self-defence.

${ }^{4}$ Here issues such as internal versus external focus of attention (the latter being the most effective) and the importance of implicit learning are at stake

For problem orientation when teaching games, the Teaching Games for Understanding (TGfU) concept (see Thorpe, Bunker \& Almond, 1986) can be helpful.

${ }^{6}$ No doubt that in the years to come the availability of digital means to support teaching and learning in movement and sport will rapidly increase. However, a warning seems to be warranted. First, teachers should guard against misuse or overuse: don't use the video camera or the tablet just because they are available. Second, teachers should be aware of the fact that over attention to video feedback might cause that the focus of attention of the students will shift from external to internal (see footnote 5).

It is incomprehensible that new gyms are still equipped with the «instruments of torture» which stem from the German «Turnen» tradition. Youngsters of today don't appear to have a strong attraction to the parallel bars or the horizontal bar; they rather prefer jumping and tumbling arrangements with springboards, trampolines and soft landings.

Retos, número 31, 2017 (1ºmestre) 